\title{
Pengembangan Modul Kalkulus dengan Pemanfaatan Software Geogebra
}

\author{
Isnaini Nur Azizah ${ }^{1 *}$, Muhammad Khoirul Amri ${ }^{2}$, Fertilia Ikashaum ${ }^{3}$, Mispani ${ }^{4}$ \\ ${ }^{1}$ Program Studi Pendidikan Islam Anak Usia Dini, Institut Agama Islam Ma'arif NU Metro Lampung \\ ${ }^{2}$ Program Studi Pendidikan Matematika, Institut Agama Islam Ma’arif NU Metro Lampung \\ 3 Program Studi Tadris Matematika, Institut Agama Islam Negeri Metro Lampung \\ 4Program Studi Pendidikan Agama Islam, Institut Agama Islam Ma'arif NU Metro Lampung
}

*Corresponding Author: zezelullaby@gmail.com

\section{ARTICLE INFO}

Article history:

Received 24 Nov 2020

Revised 16 Apr 2021

Accepted 19 May 2021

Keywords:

Calculus,

Geogebra,

Mathematics learning

module

\begin{abstract}
This study aims to produce a calculus module using geogebra software on limits, derivatives, and integrals. This research uses the 4D Thiagarajan development. This method is modified into 3D, thats define, design, and development. This research begins with a need's analysis covering student analysis, material analysis, task analysis, analysis of the formulation of learning objectives. The results of the needs analysis that the calculus module using geogebra applications needs to be developed. Based on the results of the student and teacher questionnaire responses said the module developed was very good with a value of $81 \%$.
\end{abstract}

(C) 2021 The Author(s)

Published by JRPM (Jurnal Review Pembelajaran Matematika)

This is an open access article under CC BY-SA license (https://creativecommons.org/licenses/by-sa/4.0/)

How to cite:

Isnaini Nur Azizah dkk. (2020). Desain Modul Kalkulus dengan Pemanfaatan Software Geogebra.JRPM (Jurnal Review Pembelajaran Matematika), 6(1), 13-23.

\section{PENDAHULUAN}

Modul merupakan suatu bahan ajar yang digunakan untuk menjelaskan tentang materi pembelajaran tertentu. Modul menjadi bahan pengajaran yang memudahkan siswa dalam memahami materi dan pesan pembelajaran kepada siswa (Saputri dkk., 2020; Sanjaya, 2013). Bahan ajar modul digunakan sebagai alat bantu siswa dalam mengembangkan kemampuan dan keterampilan belajar siswa. Selain itu modul juga mendorong siswa untuk belajar secara mandiri dan fokus pada pembelajaran (Sanjaya \& Budimanjaya, 2017).

Penggunaan modul sebagai bahan ajar nyatanya belum sepenuhnya dilakukan. Hasil wawancara yang dilakukan dengan guru matematika di SMAN 5 Metro menyatakan bahwa pembelajaran di sekolah masih menggunakan metode ceramah dan diskusi. Sedangkan 
sumber belajar berasal dari Lembar Kerja Siswa (LKS), buku cetak dan buku rangkuman guru. Penggunaan teknologi dalam belajar belum banyak digunakan karena keterbatasan sarana dan prasarana. Akibatnya, siswa kurang tertarik sehingga kesulitan dalam memahami materi yang dijelaskan. Selain itu sering dijumpai kesalahan-kesalahan siswa dalam mengerjakan tugas yang diberikan terutama kesalahan dalam konsep dan keterampilan berhitung, Terdapat tiga aspek kesalahan yang umum dilakukan oleh peserta didik dalam menyelesaikan soal matematika diantaranya kesalahan keterampilan, konsep dan teknik (Zukhrufurrohmah \& Kusumawardana, 2019).

Untuk memberikan solusi bagi siswa dalam memahami materi dan meminimalisir kesalahan dibutuhkan cara dan media pembelajaran lain dalam penyampaian materi seperti menggunakan modul. Untuk merancang modul pembelajaran yang baik dan efisien perlu adanya inovasi-inovasi. Salah satu inovasi tersebut yaitu dengan pemanfaatan teknologi. Penggunaan bahan ajar modul dengan berbantu teknologi akan menghasilkan bahan ajar yang menarik, efisien dan inovatif (Sungkono, 2009; Zuriah dkk., 2016; Ramadhana dkk., 2017). Selain itu bahan ajar berbasis teknologi memberikan pengaruh terhadap kemampuan komunikasi siswa (Makur, Kurniawan, \& Gunur, 2018). Hal ini dikarenakan teknologi memiliki peranan yang sangat besar dalam pengembangan bidang keilmuan serta menjadi sarana utama dunia pendidikan (Budiman, 2017; Lestari, 2018).

Kemajuan teknologi informasi dan komunikasi mengubah pandangan dan membangun suatu pola baru yaitu mematahkan anggapan lama bahwa guru merupakan sumber utama informasi. Kini seiring perkembangan teknologi yang terus maju pemanfaatan teknologi dalam pendidikan menjadi sumber belajar primer yang memberikan kesempatan kepada siswa dalam meningkatkan proses belajar (Munir, 2015). Hal tersebut selaras dengan salah satu fungsi modul pembelajaran yaitu menjadikan siswa mandiri dalam belajar agar tidak selalu bergantung kapada penjelasan guru dalam kelas (Prastowo, 2014).

Untuk mewujudkan tujuan tersebut tentunya modul pembelajaran harus disusun dengan semenarik mungkin agar siswa tertarik untuk selalu mempelajarinya. Geogebra dipilih karena software ini merupakan suatu aplikasi matematika geometri dinamis. Geogebra dapat digunakan untuk memahami dan menyelesaikan permasalahan geometri, aljabar, tabel, grafik, statistik dan kalkulus. Geogebra bisa mengontruksikan titik, vektor, ruas garis, garis, irisan kerucut, dan fungsi serta mengubahnya secara dinamis sehingga memudahkan siswa dalam belajar (Isharyadi \& Ario, 2018). Geogebra menjadi software yang sering 
digunakan untuk menyelesaikan permasalah soal geometri, aljabar, kalkulus, aritmatika dan masih banyak lainnya. Alasannya karena software ini cukup mudah untuk digunakan dalam memahami materi matematika dan juga open source atau dapat di unduh secara gratis melalui situs geogebra.org. Software ini cukup baik digunakan untuk pemahaman siswa pada tiap pembahasan materi matematika salah satunya materi kalkulus.

Kalkulus merupakan salah satu cabang ilmu matematika yang diajarkan sejak Sekolah Menengah Atas (SMA) dan dipelajari lebih mendalam di jenjang perguruan tinggi (Anisa, 2018). Rumus yang disajikan pada materi kalkulus cukup rumit sehingga dengan menggunakan software geogebra ini diharapkan pembelajaran akan lebih menarik. Geogebra juga bisa menggambarkan grafik dari suatu fungsi baik secara 2D atau 3D sehingga siswa lebih mudah untuk memahami materi.

Penelitian pengembangan bahan ajar khususnya modul memang telah banyak dilakukan dan hasilnya mempermudah proses pembelajaran (Sari et al., 2016; Isharyadi \& Ario, 2018; Hidayatulloh, 2017). Untuk itu peneliti ingin mengembangkan modul berbantu aplikasi geogebra pada materi kalkulus meliputi limit, turunan, integral dan deret tak hingga. Tujuan penelitian ini adalah untuk menghasilkan produk berupa modul pembelajaran kalkulus berbantu geogebra yang praktis dan efesien serta untuk mengetahui respon siswa terhadap produk yang dihasilkan.

\section{METODE PENELITIAN}

Penelitian ini dirancang menggunakan model 4-D Thiagarajan (Trianto, 2010). Kemudian dimodifikasi menjadi 3D yaitu pendefinisian, perencanaan, dan pengembangan karena keterbatasan waktu dan dana. Model pengembangan ini dinilai cocok dan sistematis untuk mengembangkan bahan ajar. Penerapan langkah-langkah tersebut pada penelitian ini akan disesuaikan dengan kondisi subjek, tempat penelitian dan kebutuhan pengembangan di lapangan.

Tahap awal pendefinisian yaitu melakukan analisis kebutuhan siswa yang meliputi analisis peserta didik, analisis materi, analisis tugas, dan perumusan tujuan pembelajaran. Analisis peserta didik dilakukan untuk mengetahui karakteristik peserta didik. Selanjutnya pada analisis materi dilakukan identifikasi, memperinci, dan menyusun konsep secara sistematis agar peserta didik memperoleh keterampilan dari pokok bahasan modul pembelajaran. Analisis tugas yaitu kumpulan prosedur dalam menentukan isi satuan pembelajaran (Trianto, 2010). Pengambilan data didapatkan dari wawancara kemudian 
dilakukan identifikasi terhadap keterampilan utama untuk dikaji dan dianalisis menjadi himpunan keterampilan tambahan. Tujuannya untuk memastikan ulasan keseluruhan tentang tugas pada kegiatan pembelajaran.

Hasil analisis didapatkan gambaran tentang tugas yang diperlukan dalam kegiatan pembelajaran telah sesuai standar isi. Perumusan tujuan pembelajaran merupakan kegiatan merangkum hasil analisis konsep dan analisis tugas dalam menentukan perilaku objek yang diteliti. Kumpulan dari objek tersebut menjadi dasar dalam menyusun tes dan merancang bentuk modul, kemudian diintegrasikan dengan materi pada modul. Hasil analisis ini berupa tujuan pembelajaran yang hendak dicapai.

Tahap perancangan dilakukan dengan menyiapkan produk awal perangkat pembelajaran yang akan dikembangkan. Tahap ini diantaranya pengumpulan bahan dan sumber materi, penentuan alat penilaian, struktur materi, struktur modul (tujuan, petunjuk penggunaan, kegiatan pembelajaran, rangkuman materi, tugas, latihan), penyusunan modul, pemilihan format modul, penentuan tahapan pembelajaran yang disesuaikan dengan kompetensi dasar (KD).

Tahapan dalam pengembangan bahan ajar modul dengan pemanfaatan software geogebra pada pokok bahasan kalkulus meliputi pemberian masalah awal untuk membangun pengetahuan dan mengidentifikasi masalah, menentukan hipotesis masalah, mengumpulkan data, menguji hipotesis yang telah diambil, menyimpulkan masalah, mengerjakan soal terapan. Langkah-langkah yang dilakukan pada tahap pengembangan yaitu validasi modul pembelajaran. Validasi meliputi penilaian dari ahli materi, ahli bahasa, ahli media. Validasi dilakukan untuk mengetahui apakah rancangan produk menjadi lebih menarik dari bahan ajar sebelumnya atau tidak (Azizah, 2017). Validasi ahli disebut sebagai validasi yang bersifat rasional, karena validasi ini menilai berdasarkan pemikiran rasional, belum fakta yang ada di lapangan. Berikut kriteria kelayakan modul yang diadaptasi dari Kesumayanti \& Putra (2017).

Tabel 1. Kriteria Kelayakan Modul

\begin{tabular}{ccc}
\hline Skor kualitas & Kriteria kelayakan & Keterangan \\
\hline $3,26<\bar{x} \leq 4,00$ & Sangat Valid & Tidak revisi \\
$2,51<\bar{x} \leq 3,26$ & Valid & Revisi sebagian \\
$1,76<\bar{x} \leq 2,51$ & Kurang valid & Revisi sebagian \& pengkajian ulang materi \\
$1,00<\bar{x} \leq 1,76$ & Tidak valid & Revisi total \\
\hline
\end{tabular}

Setelah produk divalidasi oleh ahli, selanjutnya dilakukan revisi hingga produk layak diuji efektifitasnya. Uji efektifitas produk dilakukan pada 8 siswa SMAN 5 Metro Kelas XI 
yang telah mempelajari materi kalkulus. Setelah itu dilakukan revisi terlebih dahulu sebelum produk diuji lapangan. Tahap terakhir dalam memberikan angket untuk mengetahui respon siswa terhadap modul yang dikembangkan.

\section{HASIL DAN PEMBAHASAN}

Hasil penelitian pada tahap define meliputi 4 aspek yaitu analisis peserta didik, analisis materi, analisis tugas, dan perumusan awal. Pada aspek analisis peserta didik didapat hasil bahwa motivasi belajar siswa masih rendah. Hal ini disebabkan siswa kurang tertarik terhadap pelajaran matematika. Hasil ini didapat dari wawancara dengan guru matematika. Guru sudah menggunakan media pembelajaran dalam membantu siswa belajar, namun hasil menunjukkan bahwa hanya 30\% siswa yang merasa puas dengan penjelasan guru dan $70 \%$ masih kesusahan dalam memahami materi. Selain itu, hasil angket kebutuhan siswa menunjukkan bahwa 55\% siswa menginginkan alternatif media baru dalam pembelajaran matematika.

Pada aspek materi dilakukan analisis terhadap kurikulum yang digunakan dalam pembelajaran di kelas. Kurikulum yang digunakan di SMAN 5 Metro adalah kurikulum K13 dan materi yang digunakan terfokuskan pada materi kalkulus SMA yang meliputi limit, turunan, dan integral. Pada aspek analisis tugas didapatkan hasil tentang struktur isi dari modul pembelajaran yang mencakup judul modul pembelajaran, petunjuk penggunaan modul, daftar isi, kompetensi dasar serta materi modul, contoh soal, rangkuman, dan latihan soal.
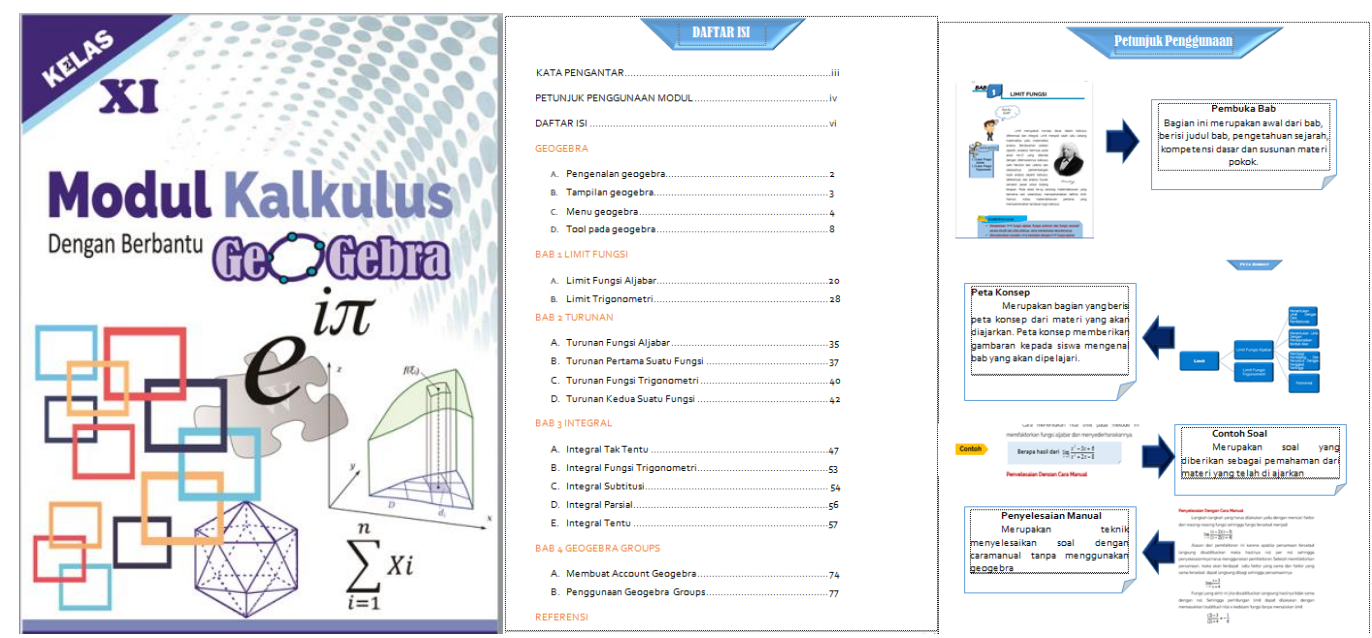

Gambar 1. Hasil Pengembangan Modul yang Telah Dilakukan

Hasil yang didapatkan dari tahap design yaitu penyusunan format dan penentuan tahapan pembelajaran didapatkan bahwa penyusunan format meliputi penyesuaian dengan 
KI dan KD serta silabus berdasarkan kurikulum yang digunakan di SMAN 5 Metro. Kemudian penentuan tahapan dalam pembelajaran yaitu dengan pemberian masalah, menduga jawaban, pengumpulan data, menguji hipotesis, membuat kesimpulan, dan mengerjakan soal.

Pada tahap development yaitu setelah setiap aspek selesai dianalisis maka langkah berikutnya yaitu validasi terhadap produk. Validasi dilakukan oleh ahli materi, ahli bahasa, dan ahli media. Ahli adalah dosen yang berkompeten di bidangnya. Adapun rangkuman revisi dari ahli disajikan pada Tabel 2 berikut.

Tabel 2. Rangkuman Revisi dari Ahli

\begin{tabular}{clll}
\hline No & Aspek yang dinilai & \multicolumn{1}{c}{ Catatan } & \multicolumn{1}{c}{ Revisi } \\
\hline 1 & Kelengkapan modul & $\begin{array}{l}\text { Terlebih dahulu dikenalkan apa itu } \\
\text { geogebra, cara instalasi dan cara } \\
\text { mendownload master }\end{array}$ & $\begin{array}{l}\text { Menambahkan pengenalan geogebra, } \\
\text { cara instalasi dan cara mendownload } \\
\text { master pada awal modul sebelum } \\
\text { masuk ke materi } \\
\text { Contoh soal di tambahkan dengan } \\
\text { beberapa soal yang lebih bervariatif } \\
\text { Memperbaiki cover dengan desain }\end{array}$ \\
3 & Materi modul & Perlu penambahan contoh soal & $\begin{array}{l}\text { yang lebih menarik } \\
\text { Refisi penulisan dan EYD }\end{array}$ \\
4 & Penggunaan bahasa & $\begin{array}{l}\text { Periksa penggunan kalimat baku } \\
\text { dan EYD }\end{array}$ & \\
\hline
\end{tabular}

Sedangkan rekapitulasi validasi ahli terhadap modul yang dikembangkan disajikan pada Tabel 3 berikut.

Tabel 3. Nilai Rata-Rata Validasi

\begin{tabular}{cccc}
\hline Perangkat & Validasi Materi & Validasi Bahasa & Validasi Desain \\
\hline Rata-Rata Validasi & 3.3 & 3,4 & 3,6 \\
Kriteria & Sangat Valid & Sangat Valid & Sangat Valid \\
\hline
\end{tabular}

Pada Tabel 3 didapatkan rata-rata validasi perangkat mulai dari validasi materi, validasi bahasa, dan validasi desain termasuk kriteria sangat valid. Selanjutnya dilakukan uji terbatas terhadap 8 siswa. Subjek uji terbatas diberikan modul kalkulus berbantu geogebra. Hasil ratarata skor posttest yang diperoleh 82. Skor ini di atas KKM yang ditentukan yaitu 75 .

Selanjutnya produk diuji coba lapangan terhadap 20 siswa SMAN 5 Metro. Hasil ujicoba lapangan diperoleh skor rata-rata hasil posttest 78. Skor ini telah memenuhi standar KKM yang ditentukan yaitu 75 . Untuk mengetahui respon siswa dan guru terhadap modul dilakukan penilaian respon siswa dan respon guru menggunakan angket. Adapun kriteria respon siswa dan tanggapan guru disajikan pada Tabel 4 berikut. 
Tabel 4. Kriteria Respon Siswa dan Tanggapan Guru

\begin{tabular}{cc}
\hline Persentase Skor & Kriteria Skor \\
\hline $\mathrm{x}>80 \%$ & Sangat baik \\
$61 \% \leq \mathrm{x}<80 \%$ & Baik \\
$41 \% \leq \mathrm{x}<60 \%$ & Cukup Baik \\
$21 \% \leq \mathrm{x}<40 \%$ & Kurang Baik \\
$\mathrm{x}<21 \%$ & Tidak Baik \\
\hline
\end{tabular}

Berdasarkan pada Tabel 5 dan Tabel 6 di bawah ini didapatkan hasil respon peserta didik dan tanggapan guru. Hasil respon peserta didik berdasarkan hasil angket menunjukkan skor 81\% dengan kategori "Sangat Baik", dan hasil dari respon tanggapan guru menunjukkan skor 81\% dengan kategori "Sangat Baik". Dengan demikian modul pembelajaran layak dan baik digunakan untuk pembelajaran.

Tabel 5. Respon Peserta Didik Terhadap Modul

\begin{tabular}{|c|c|c|}
\hline No. & Pernyataan & Skor \\
\hline 1 & $\begin{array}{l}\text { Modul ini menggunakan masalah yang berkaitan dengan pemanfaatan teknologi dalam } \\
\text { mengantarkan suatu konsep }\end{array}$ & 72 \\
\hline 2. & Modul ini menggunakan soal-soal yang diselesaikan dengan software matematika & 91 \\
\hline 3. & Materi dalam modul dimulai dari yang mudah ke yang sukar & 82 \\
\hline 4. & Isi modul ini sesuai dengan materi kalkulus SMA yaitu limit, turunan, dan integral & 89 \\
\hline 5. & Pada modul ini terdapat bagian dimana saya dapat menemukan konsep sendiri & 92 \\
\hline 6. & Modul ini mendorong saya untuk merangkum materi sendiri & 92 \\
\hline 7. & $\begin{array}{l}\text { Modul ini memuat tes yang dapat menguji seberapa jauh pemahaman saya terhadap materi } \\
\text { kalkulus SMA yaitu limit, turunan, dan integral }\end{array}$ & 88 \\
\hline 8. & $\begin{array}{l}\text { Penyajian materi dalam modul ini mendorong saya untuk berdiskusi dengan teman-teman } \\
\text { yang lain }\end{array}$ & 81 \\
\hline 9. & Saya dapat menggunakan modul ini dengan mudah meski tanpa bimbingan guru & 72 \\
\hline 10. & Dengan menggunakan modul ini dapat membuat belajar saya lebih terarah dan runtut & 81 \\
\hline 11. & Materi dalam modul ini mendorong keingintahuan saya & 86 \\
\hline 12. & Modul ini mendorong saya untuk berfikir & 80 \\
\hline 13. & $\begin{array}{l}\text { Modul ini memotivasi saya untuk belajar materi kalkulus SMA yaitu limit, turunan, dan } \\
\text { integral }\end{array}$ & 79 \\
\hline 14. & Tampilan dan desain modul ini menarik & 76 \\
\hline 15. & Kalimat dan paragraf modul ini jelas dan mudah dipahami & 81 \\
\hline 16. & Huruf yang digunakan sederhana dan mudah dibaca & 80 \\
\hline 17. & Bahan dan ukuran modul ini sudah sesuai dengan kebutuhan saya & 74 \\
\hline 18. & $\begin{array}{l}\text { Dengan menggunakan modul ini saya lebih mudah memahami materi kalkulus SMA yaitu } \\
\text { limit, turunan, dan integral }\end{array}$ & 71 \\
\hline 19. & Saya masih sulit memahami materi kalkulus SMA yaitu limit, turunan, dan integral & 69 \\
\hline 20. & $\begin{array}{l}\text { Dengan modul ini saya semakin mengenal software atau aplikasi yang dapat digunakan } \\
\text { dalam membantu pemahaman materi pembelajaran. } \\
\text { Jumlah }\end{array}$ & $\begin{array}{c}81 \\
1617\end{array}$ \\
\hline & Persentase & $81 \%$ \\
\hline
\end{tabular}


Tabel 6. Hasil Tanggapan Guru

\begin{tabular}{|c|c|c|}
\hline No & Pernyataan & Skor \\
\hline 1. & $\begin{array}{l}\text { Modul ini menggunakan ilustrasi masalah yang berkaitan dengan perkembangan teknologi } \\
\text { dalam mengantarkan suatu konsep }\end{array}$ & 5 \\
\hline 2. & Modul ini menggunakan contoh-contoh soal yang dikaitan dengan teknologi & 5 \\
\hline 3. & Penyajian materi dalam modul di mulai dari yang mudah hingga sukar & 4 \\
\hline 4. & $\begin{array}{l}\text { Penyajian komponen modul ini disesuaian dengan materi (Apersepsi, mengingat kembali, } \\
\text { kegiatan siswa, contoh soal, latihan, uji kompetensi, motivasi Jawa, kamus budaya dll) }\end{array}$ & 4 \\
\hline 5. & Isi modul ini sesuai dengan kalkulus SMA yaitu limit, turunan, dan integral & 5 \\
\hline 6. & Tampilan dan desain modul ini menarik & 4 \\
\hline 7. & Pemilihan gambar dan font huruf sesuai dan mudah dibaca & 4 \\
\hline 8. & Pemilihan ukuran dan bahan modul sudah tepat & 4 \\
\hline 9. & Instruksi yang digunakan dalam modul jelas dan mudah dipahami & 5 \\
\hline 10. & Bahasa yang digunakan jelas dan mudah dipahami & 5 \\
\hline 11. & Penyajian komponen dalam modul mudah dipahami & 5 \\
\hline 12. & Modul ini baik sebagai bahan ajar yang terintegrasi dengan perkembangan teknologi & 4 \\
\hline 13. & $\begin{array}{l}\text { Modul ini baik dalam membantu siswa untuk memahami materi kalkulus SMA yaitu limit, } \\
\text { turunan, dan integral }\end{array}$ & 5 \\
\hline 14. & Penggunaan modul ini baik untuk mendukung kegiatan belajar matematika siswa di kelas & 5 \\
\hline 15. & Penggunaan modul ini baik untuk mendukung kegiatan belajar matematika siswa di rumah & 5 \\
\hline \multirow[t]{3}{*}{16.} & Modul ini baik sebagai sumber belajar matematika & 4 \\
\hline & Jumlah & 73 \\
\hline & Persentase & $81 \%$ \\
\hline
\end{tabular}

Prosedur penelitian ini menggunakan metode pengembangan 4D yang dikembangkan oleh Thiagharajan. Selanjutnya dimodifikasi menjadi 3D dengan langkah Define, Design, dan Develop. Pengembangan bahan ajar ini dimulai dengan penemuan potensi dan masalah yang dilakukan oleh peneliti dengan melalukan observasi di SMAN 5 Metro. Observasi dilakukan dengan cara wawancara dan angket kebutuhan. Wawancara dilakukan dengan guru mata pelajaran matematika dan siswa. Sedangkan, angket dilakukan untuk mencari permasalahan yang dihadapi siswa dalam belajar, khususnya pelajaran matematika.

Dalam pengembangan bahan ajar ini seluruhnya telah disesuaikan dengan tahapantahapan model pengembangan. Desain halaman bahan ajar matematika dengan pemanfaatan software geogebra telah melalui tahapan-tahapan validasi oleh ahli materi, ahli bahasa dan ahli desain. Setelah tahapan dilalui dilakukan perbaikan-perbaikan sesuai saran dan komentar serta telah sesuai dengan kompetensi inti dan kompetensi dasar yang ditetapkan Badan Standar Nasional Pendidikan (BSNP), sehingga bahan ajar matematika dengan pemanfaatan software geogebra yang dikembangkan telah dinyatakan layak digunakan. Jika produk dikembangkan dengan dasar teoritik yang kuat maka produk yang dikembangkan memiliki konsistensi secara internal (McKenney, S., \& Reeves, 2014).

Selanjutnya dilakukan uji terbatas dengan hasil rata-rata posttest 82. Berdasarkan perbandingan dengan KKM maka produk ini dinyatakan dapat digunakan untuk uji 
lapangan. Hasil uji lapangan dengan nilai rata-rata posttest 78. Selain itu, bahan ajar yang baik adalah bahan ajar yang menarik bagi peserta didik dan pendidik sebagai pengguna bahan ajar. Oleh karena itu, untuk mengetahui tingkat kelayakan modul dengan pemanfaatan software geogebra pada materi limit, turunan, dan integral maka diberikan angket untuk mengetahui respon siswa dan guru.

Hasil pembagian angket respon siswa kemudian dianalisis untuk mengetahui apakah siswa memberikan respon yang baik atau tidak. Hasil yang diperoleh menunjukkan rata-rata skor 81\% dengan kategori "Sangat Baik". Hasil angket respon guru menunjukkan rata-rata skor 81\% dengan kategori "Sangat Baik". Dari hasil respon siswa dan respon guru maka dapat disimpulkan bahwa modul pembelajaran matematika dengan pemanfaatan software geogebra layak untuk digunakan.

Berdasarkan validasi dan revisi yang telah dilakukan serta uji coba yang telah dilakukan, maka tujuan pengembangan untuk menghasilkan produk berupa bahan ajar modul dengan pemanfaatan software geogebra pada materi kalkulus SMA yaitu limit, turunan, dan integral sudah sesuai dengan tujuan pengembangan. Bahan ajar modul matematika dengan pemanfaatan software geogebra yang telah dikembangkan diharapkan dapat membantu peserta didik dalam memahami materi efektif sebagai sumber belajar peserta didik yang lebih baik lagi, membuat peserta didik lebih tertarik untuk belajar matematika.

\section{SIMPULAN DAN SARAN}

Hasil penelitian yang diperoleh yaitu suatu produk bahan ajar berbantu teknologi dalam membantu siswa dalam memahami materi kalkulus SMA yang meliputi materi limit, turunan, dan integral. Bahan ajar ini terintegrasi dengan teknologi yaitu software geogebra. Pemilihan geogebra dalam modul ini karena geogebra sangat mudah digunakan dan free akses.

Struktur isi modul pembelajaran ini meliputi judul modul pembelajaran, petunjuk penggunaan modul pembelajaran, KD dan materi modul pembelajaran, contoh soal, rangkuman, dan latihan. Tujuan pembuatan modul untuk menambah wawasan siswa tentang teknologi yang dapat membantu pemahaman siswa. Hasil penelitian dari penilaian para ahli yang menunjukkan bahwa modul tersebut valid dari aspek materi, Bahasa, dan desain, serta respon siswa dan tanggapan guru yang menunjukkan kriteria sangat baik, Jadi modul tersebut layak dan baik digunakan dalam membantu peserta didik dalam memahami materi kalkulus SMA yang meliputi materi limit, turunan, dan integral. Dalam penelitian masih terbatas dalam pengujian sehingga masih perlu untuk dikembangkan lebih dalam dan 
diujikan lebih detail lagi untuk memperoleh produk yang sangat baik untuk membantu siswa.

\section{DAFTAR RUJUKAN}

Anisa, T. W. (2018). Pengembangan Bahan Ajar Mata Kuliah Kalkulus Vektor untuk Meningkatkan Kemampuan Berpikir Kritis Matematis. Jurnal Review Pembelajaran Matematika, 3(2), 102-113. https://doi.org/10.15642/jrpm.2018.3.2.102-113.

Azizah, I. N. (2017). Lembar Kerja Peserta Didik Materi Aritmatika Sosial dengan Model Pengembangan Thiagarajan. NUMERICAL: Jurnal Matematika dan Pendidikan Matematika, 1(2), 127-146. https://journal.iaimnumetrolampung.ac.id/index.php/numerical/article/view/132/1 $\underline{38}$.

Budiman, H. (2017). Peran Teknologi Informasi Dan Komunikasi Dalam Pendidikan. AlTadqkiyyah: Jurnal Pendidikan Islam, 8(1), 31. https://doi.org/10.24042/atjpi.v8i1.2095.

Hidayatulloh, M. S. (2017). Pengembangan E- Modul Matematika Berbasis Problem Based Learning Berbantuan Geogebra Pada Materi Bilangan Bulat. Aksioma, 7(2), 24. https://doi.org/10.26877/aks.v7i2.1416.

Isharyadi, R., \& Ario, M. (2018). Pengembangan modul berbantuan geogebra pada perkuliahan geometri transformasi. Jurnal Pendidikan dan Pembelajaran, 1(1), 1-8.

Kesumayanti, N., \& Putra, R. W. Y. (2017). Pengembangan Bahan Ajar Materi Persamaan Kuadrat Berbantuan Rumus Cepat. JES-MAT (Jurnal Edukasi dan Sains Matematika), 3(2), 125. https://doi.org/10.25134/jes-mat.v3i2.686.

Lestari, S. (2018). Peran Teknologi dalam Pendidikan di Era Globalisasi. Edureligia; Jurnal Pendidikan Agama Islam, 2(2), 94-100. https://doi.org/10.33650/edureligia.v2i2.459.

McKenney, S., \& Reeves, T. C. (2014). Educational design research. In Handbook of Research on Educational Communications and Technology:

Makur, A. P., Kurniawan, Y., \& Gunur, B. (2018). Pengaruh Penggunaan Bahan Ajar Berbasis Android dan Tipe Kepribadian Terhadap Kemampuan Komunikasi Matematis Calon Guru. Jurnal Review Pembelajaran Matematika, 3(2), 86-101

Munir. (2015). Multimedia: konsep \& aplikasi dalam pendidikan, 3rd ed. Alfabeta.

Prastowo, A. (2014). Bahan ajar tematik teoritis dan praktek. Kencana.

S.Sirate, S. F., \& Ramadhana, R. (2017). Pengembangan Modul Pembelajaran Berbasis Keterampilan Literasi. Inspiratif Pendidikan, 6(2), 316. https://doi.org/10.24252/ip.v6i2.5763.

Sanjaya, W. (2013). Strategi Pembelajaran Berorientasi Standar Proses Pendidikan. Kencana. http://library.um.ac.id/free-contents/index.php/buku/detail/strategi-pembelajaranberorientasi-standar-proses-pendidikan-wina-sanjaya-34179.html

Sanjaya, W., \& Budimanjaya, A. (2017). Paradigma Baru Mengajar. Kencana.

Saputri, N., Azizah, I. N., \& Hernisawati, H. (2020). Pengembangan Bahan Ajar Modul dengan Pendekatan Discovery Learning pada Materi Himpunan. Jambura Journal of Mathematics Education, 1(2), 48-58. https://doi.org/10.34312/jmathedu.v1i2.5594. 
Sari, F. K., Farida, \& M.Syazali. (2016). Pengembangan Media Pembelajaran (Modul) berbantuan Geogebra Pokok Bahasan Turunan. Jurnal Pendidikan Matematika, 7(2), 135-152. http://ejournal.radenintan.ac.id/index.php/al-jabar/article/view/24.

Sungkono, S. (2009). Pengembangan Dan Pemanfaatan Bahan Ajar Modul Dalam Proses Pembelajaran. Majalah Ilmiah Pembelajaran, 5(1).

Trianto. (2010). Model Pembelajaran Terpadu: Konsep, Strategi, dan Implikasinya dalam Kurikulum Tingkeat Satuan Pendidikan (KTSP). Bumi Aksara.

Zukhrufurrohmah, Z., \& Kusumawardana, A. S. (2019). Analisis Kesalahan Matematis Mahasiswa Teknik Sipil pada Mata Kuliah Kalkulus II. Jurnal Review Pembelajaran Matematika, 4(1), 1-10. https://doi.org/10.15642/jrpm.2019.4.1.1-10.

Zuriah, N., Sunaryo, H., \& Yusuf, N. (2016). IbM Guru dalam Pengembangan Bahan Ajar Kreatif Inovatif Berbasis Potensi Lokal. Dedikasi, 13, 40. 1693-3214. 